\title{
両側突発難聴で判明した白血病例
}

\author{
菊川 達雄・野々村光栄・大野 恒久
}

\section{A Case of Leukemia Revealed by Bilateral Sudden Hearing Impairment}

\author{
Tatsuo Kikugawa, Mitsuharu Nonomura and Tsunehisa Ohno \\ (Shizuoka City Hospital)
}

\begin{abstract}
A 30-year old man was admitted to Shizuoka City Hospital because of bilateral sudden hearing impairment. He was pale and manifested hepato-splenomegaly. A blood examination revealed chronic myelocytic leukemia in blastic crisis with DIC. He died of multiple cerebral hemorrhages 4 days after his initial visit.
\end{abstract}

Key words : sudden hearing impairment, chronic myelocytic leukemia, blastic crisis

はじめに

白血病患者に耳鳴, 難聴, めまいといった耳症状がみ られたとする報告は数多く，白血病に伴う耳症状の頻度 はかなり高いことが知られている。しかし，本邦に括け る報告例はあまり多くない，今回われわれは，難聴を主 訴に当科を初診し，その 4 日後に不幸な転帰をとった白 血病の 1 例を経験したので, 若干の文献的考察を行い報 告する.

\section{症例}

症例 : 30歳, 男性.

主訴：両側難聴.

現病歷: 平成12年10月17日頃, 急に両耳に難聴が出現 し，2 日後に当科を初診した.

既往歴：いわゆる“ひきこもり”の状態(約 6 年前か ら).

初診時所見：外耳, 鼓膜には肉眼的に異常なし. 顔面 神経麻瘒なし、めまいの訴えはなかったが，左向き自発 眼振を認めた。純音聴力検査では, 左耳は襲で, 右耳は 平均聴力レベル $50 \mathrm{~dB}$ ( 3 分法) の感音難聴であった(図 1).これらの耳症状以外に著明なるいそらと巨大肝脾 腫を認め, 顔色は不良で歩行困難であった. 全身状態不 良で，一見して重篤な全身疾患を伴っているのは明らか
であった。

末梢血液検査: 白血球 $7.0 \times 10^{5} / \mathrm{mm}^{3}$, 分画(骨髄芽球 $18 \%$, 前骨髄球 $24 \%$, 骨䯣球 $22 \%$, 後骨䯣球 $14 \%$, 好中 球 $14 \%$, 好酸球 $2 \%$, 好塩基球 $6 \%$ ), へモグロビン 4.0 $\mathrm{g} / \mathrm{dl}$, 血小板 $4.0 \times 10^{4} / \mathrm{mm}^{3}$, PT $25.6 \%$, APTT 83.6

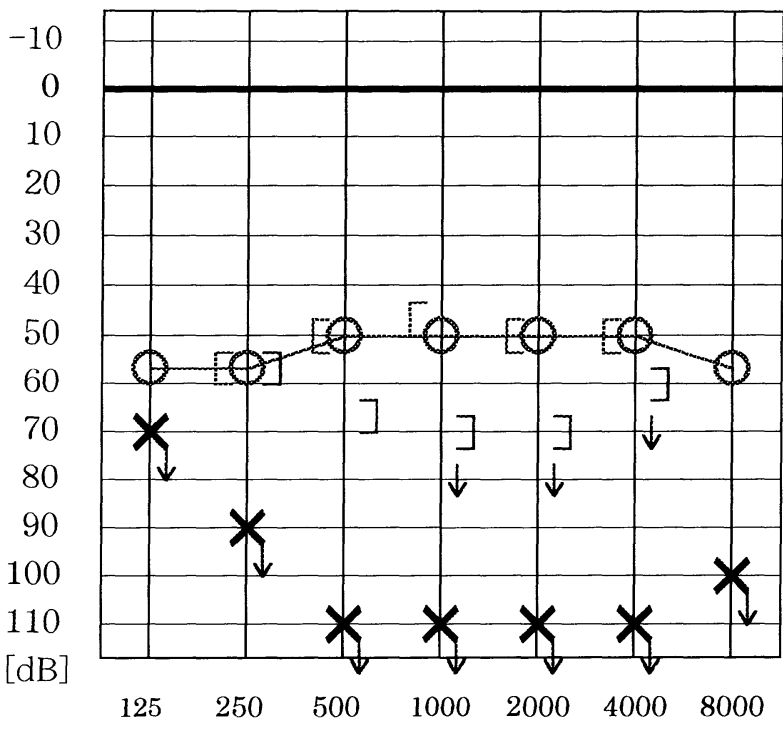

周 波 数 $[\mathrm{Hz}]$

図 1 純音聴力検査(10月19日) 


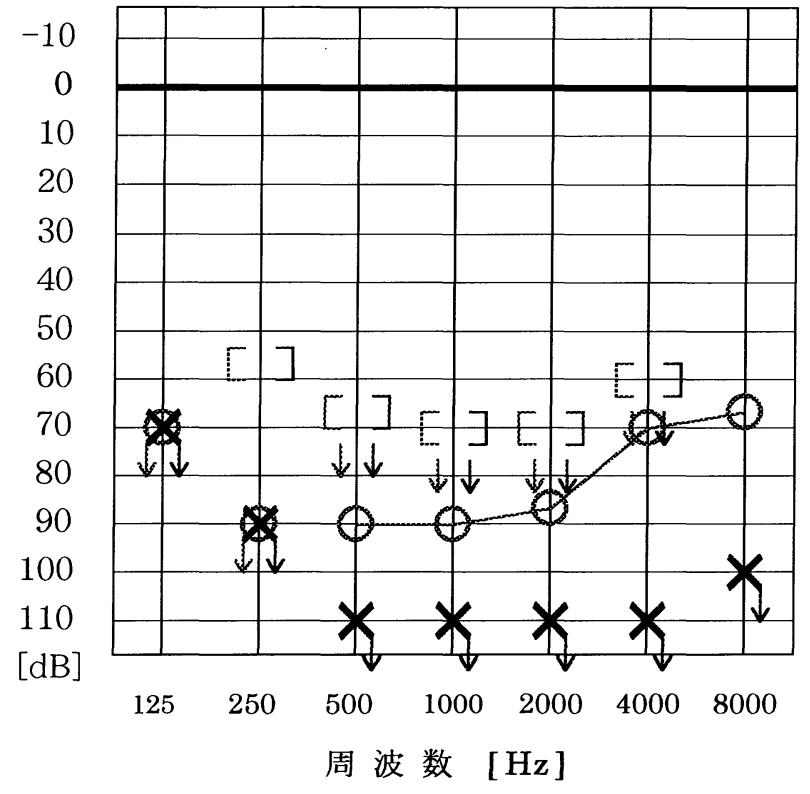

図 2 純音聴力検查(10月20日)

\section{\%, AT-III 76.0\%, フィブリノーゲン $81.9 \mathrm{mg} / \mathrm{dl}$.}

入院経過: 末梢血液検查で白血球数は $7.0 \times 10^{5} / \mathrm{mm}^{3}$, 分画で骨髄芽球 $18 \%$, 前骨骨道球 $24 \%$ とあわせて $40 \%$ 以上 で，慢性骨䯣性白血病急性転化と診断された。

10 月 20 日, 血液内科に入院したが，難聴はさらに悪化 した．左耳はスケールアウトのままで不変だったが，右 耳は平均聴力 $88 \mathrm{~dB}$ まで急激に低下した(図 2 )。この 際, DICを合併していたこともあり, 頭蓋内病変を疑っ て頭部 CT を行ったが, 明らかな異常を認めなかった(図 3 上)。しかし，翌日には意識レベルが低下したため， 再度 CTを行ったところ, 多発性脳出血を認めた（図 3 下)。その翌日10月22日午前 4 時に患者は死亡した。

\section{考察}

1. 白血病に伴 5 耳症状の頻度について 19世紀半ばから白血病に伴ら難聴の報告はみられ，白 血病患者に耳症状が出現することはよく知られている. Druss ${ }^{1)}$ は $16.8 \%$ ， Love ${ }^{2)}$ は25.8\%, Shanbrom ら) は $27.0 \%$ に耳症状がみられたとして扣り，その出現頻度は 約 $20 \%$ 前後と考えられている4)。 これは貧血, 発熱, 肝 脾腫, 出血傾向といった白血病の中核症状の出現率と比 ベるとはるかに低い，しかし，実際にはもっと高い頻度 で耳症状が出現していると推察されていて，本邦では相 川ら5゙が50\%に何らかの耳症状が認められたと報告して
いる.

そもそも白血病患者に耳症状が起さるのは，側頭骨に 白血病性変化が生じるためと考觉られているが，生前に 耳症状がなかったとされる症例でも, 剖検で側頭骨に白 血病細胞の浸潤や出血, 感染といった特徵的な変化がみ られることがきわめて多いといわれている.こうした症 例では実際には何らかの耳症状が出現していたにもかか わらず，見落とされていた可能性が高いと考えられる. 白血病では, 内科的診察, 治療が優先されるために耳症 状に気付かれない場合や，患者自身が全身状態不良のた めに耳症状があっても症状を訴えずに見逃されることも 多いのではないかと思われる.

2. 白血病の難聴の型と成因について

白血病性変化は多岐にわたり, 外耳, 中耳, 内耳と側 頭骨内のいずれの部位にも病変が生じるので, 病変の部 位に応じて, 伝音性, 感音性, あるいは混合性といずれ のタイプの難聴もきたすと考えられている6).

一般に，白血病細胞の浸潤がみられやすい部位として， 外耳道皮下組織, 中耳粘膜, 側頭骨骨髄, 鼓膜などが挙 げられ, 出血は内耳道, 顔面神経, 中耳腔, 耳管などに 起こりやすいとされている.

諸家により白血病による感音難聴の成因について，側 頭骨病理に基ついた推論がなされているが，Love2)は， 感音難聴を臨床経過から突発的に耳鳴, 難聴, めまいを きたすタイプと比較的急速に難聴が進行するタイプに分 けて考觉ている. 突発難聴の原因としては主に内耳出血 が，急速に進行するタイプの原因としては，内耳への白 血病細胞浸潤が主な原因と推論している. 一方 Stefani? は, 慢性骨髄性白血病の経過中に両側突発難聴をきたし た症例について, 内耳病変が軽度で, 第 8 脳神経への細 胞浸潤や出血, 浮腫性変化といった後迷路性障害が感音 難聴の原因と考えられたと報告している. また, 坂本 $ら^{8)}$ は内耳出血による内耳障害が感音難聴の原因と考劣 られた症例と, 髄膜白血病から頭蓋内, ことに聴神経へ の細胞浸潤が聴覚障害の主要因と推定された症例を報告 した.

3. 本例に関して

本例は両側感音難聴で, 難聴を自覚してから 2 日後に 当科を受診しているが，初診時すでに左耳は壟であった。 右耳は平均聴力 $50 \mathrm{~dB}$ で，翌日には $88 \mathrm{~dB}$ まで急激に 進行した．本例の感音難聴の原因については，剖検が行 われていないので病理学的な裏付けがないまた，もと 

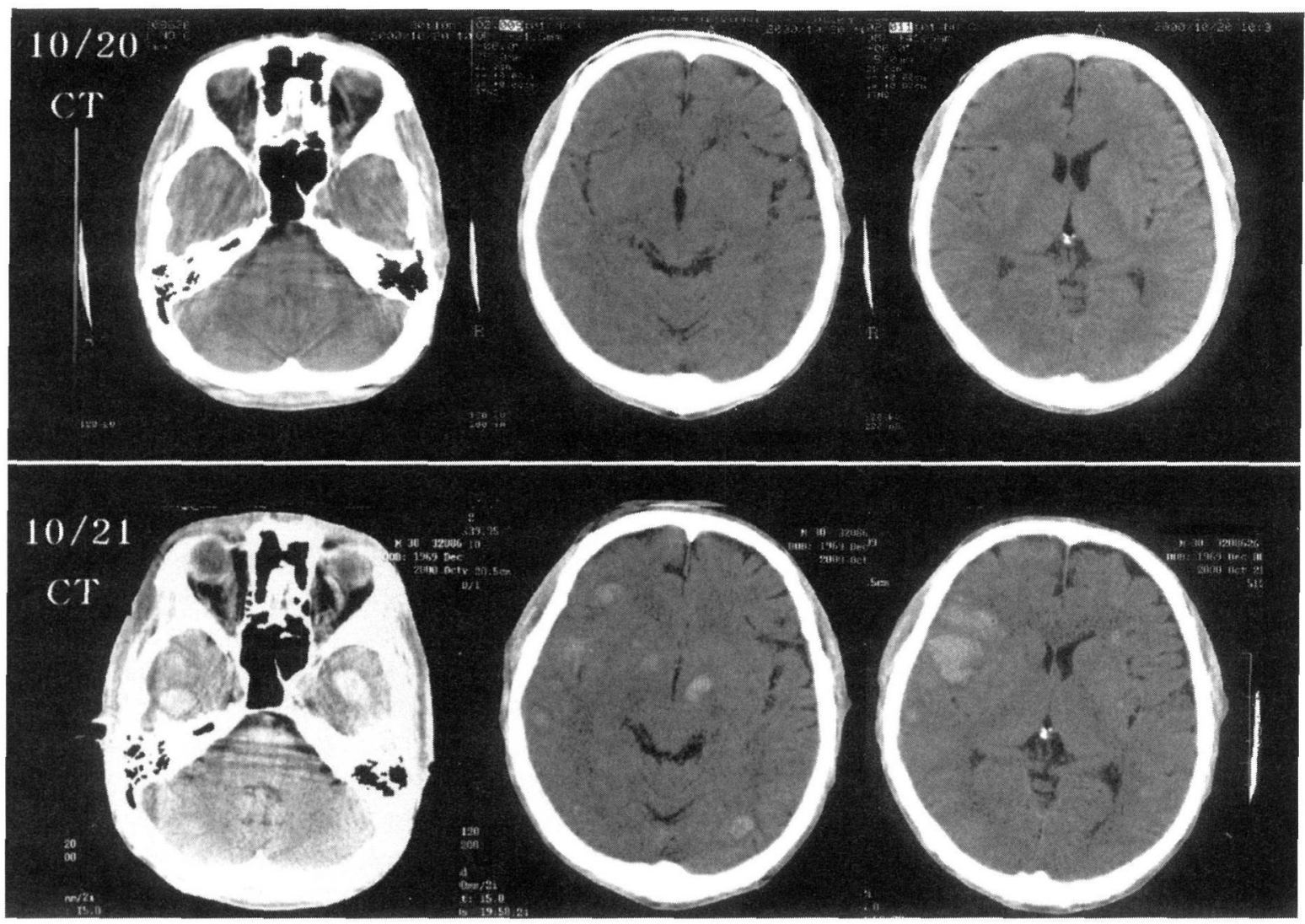

図 3 単純頭部 $\mathrm{CT}$ 所見 上段(10月20日）；明らかな異常なし.

下段(10月21日); 多発性脳出血を認める.

もと全身状態が不良でさらに急激に状態が悪化したため, 十分な神経耳科学的な検査も行らことができなかった。 そこで原因を推論するにあたって, 文献的に似通った臨 床経過をとったと思われる土田ら 9) の側頭骨病理報告例 は貴重な参教資料であると考える。彼ら ${ }^{9)}$ は, 本例と同 じく慢性骨髄性白血病(末梢血液検查で白血球数 $5.0 \times$ $10^{5} / \mathrm{mm}^{3}$ ) でDIC 拿併し, 死の4 日前に両側之もに汪 ぼ襲に近い状態末で急速に進行した症例を報告している. 彼ら ${ }^{9}$ は，側頭骨病理所見として「蝸牛には出血が強く らせん器も破壊されていた。基底版の破壊が一部にみら れた. 前庭では外リンパ腔への出血が著しく, 卵形囊斑, 球形囊斑, 三半規管膨大部稜への細胞浸潤が強かった. 内耳道内には出血执よび細胞浸潤が強かった. 中耳の変 化は軽微であった.」と述べ，「死後時間が長いこともあ り, 難聴発現時の内耳の状態を正確につかもことは困難 である・」としながらも,「難聴の原因としては, 循環障
害，膜迷路の破綻，内外リンパの混合などが総合的に蝸 牛の機能に影響したものと考光られる.」と推論してい る. 本例も慢性骨髄性白血病急性転化例で，末梢血液検 查では白血球数 $7.0 \times 10^{5} / \mathrm{mm}^{3}$ と異常增加して物り, DIC 学併していたことから，出血や微小血管の塞栓 による循環障害, 白血病細胞浸潤が内耳户内耳道内に起 きていたと推察される。

また，本例は難聴を主訴に初めて当院を受診したが， 初䛦時に一見してわかる著明な肝脾腫, るいそら, 貧血 を認めた。血液内科に入院し治療されたが，初診から4 日後には多発性脳出血をきたして死亡した。これほど受 診が遲くなったのは，いわゆる“ひさこもり”10)が原因 で，母親が変調に気付きながらも患者を病院に連れて来 られなかったためであった。このよらな特殊な背景の症 例でなくても, 白血病と診断される前に耳症状を呈する ものが $5 \sim 10 \%$ 程度あるといわれている. 野及村ら4) 
耳鼻科医は白血病患者が経過中に耳症状を呈することが 予想以上に存在すること，また耳症状を初発症状とする 白血病が存在することを認識し，十分な検索を行う必要 があると述べている.

また大蔵ら ${ }^{6)}$ は，さまざまな難聴を呈した白血病の 4 症例を報告し，それらの難聴発生から死に至るまでの期 間が，最短12日最長 2 カ月と短かかったことから，白血 病患者の経過中に生じる難聴は予後を示唆する重要な因 子の一つと考光ている，そして，白血病症例に難聴が生 じた場合, 背景に脳出血, 䯣膜白血病やDICなどが隠 されている場合が多く，注意するべきであると述べてい る.

本例も難聴を自覚してから約 1 週間で死亡するといら 急激な臨床経過をとっているが，やはりDICを合併し ており, 難聴を自覚してから 5 日目に多発性脳出血をき たしている．現状ではいまだに慢性骨䯣性白血病の急性 転化後の有効な治療法はなく, 平均余命は $3 \sim 6$ 力月と いわれている11)。もともと予後は非常に厳しい疾患であ るが，感音難聴は出血や循環障害が原因である可能性が 高いので，全身状態の悪化を反映する重要な因子と思わ れた.

\section{まとめ}

以上，いわゆる“ひきこもり”の患者で，両側の急性 感音難聴を契機として受診し，初診から 4 日目に死に 至った慢性骨䯣性白血病急性転化の 1 例を報告した.

\section{参考文献}

1) Druss JG : Aural manifestation of leukemia. Arch Otolaryngol $42: 267 \sim 274,1945$.

2 ) Love AA : Manifestation of leukemia encountered in otolaryngologic and stomatologic practice. Acta Otolaryngol $23: 173 \sim 221,1936$.

3 ) Shanbrom E and Finch SC : The auditory manifestation of leukemia. Yale J Biol Med 31 : 144 156, 1958.

4 ) 野々村直文, 大竹欣哉: 耳症状を呈した白血病の 2 症例. 耳鼻臨床 $77: 779 \sim 784,1984$.

5 ) 相川 通, 大谷 篊, 村上正文, 他: 白血病の側頭骨病理. 耳鼻臨床 補32：56～60, 1989.

6 ）大蔵眞一，加我君孝 : 難聴を呈した白血病 4 症例の側頭骨 病理. Audiology Japan $34: 104 \sim 109,1991$.

7 ) De Stefani GB : Studio clinico e istopatologico dell' apparato cocleovestibolare in leukemico. Arch Ital Otol $67: 638 \sim 652,1956$.

8 ）坂本伸一郎, 鈴木史人, 真柄孝一, 他 : 白血病に伴った感 音性難聴の 2 症例. 日耳鼻 $77: 255 \sim 264,1974$.

9）土田み水子, 川端五十鈴, 野村恭也：白血病症例に打ける 側頭骨所見. 耳鼻臨床 $74: 295 \sim 301,1981$.

10）福田真也：臨床医が知って扣きたいメンタルヘルス一ひ きこもり一. 日本医事新報 $3942: 41 \sim 47,1999$.

11）内藤健助, 大野竜三 : 慢性骨䯣性白血病の急性転化. 日常 訩療と血液 $8: 1433 \sim 1441,1998$.

$\left.\begin{array}{l}\text { 原稿受付 : 平成 } 13 \text { 年 } 7 \text { 月 } 11 \text { 日 } \\ \text { 原稿採択 : 平成 } 13 \text { 年 } 9 \text { 月 } 5 \text { 日 急載 } \\ \text { 別刷請求先 : 菊川達雄 } \\ \text { ₹ } 420-8630 \text { 静岡市追手町 } 10-93 \\ \text { 静岡市立静岡病院耳鼻咽喉科 }\end{array}\right)$

